\title{
Analysis of Agricultural Commodities Value Chains and Greenhouse Gas Emission in Rice and Maize in West Africa: Impact on Food Security
}

\author{
Mahamadou Nassirou Ba \\ Food Security, Agriculture and Land Section in the Regional Integration and Trade Division, United Nations \\ Economic Commission for Africa, Addis Ababa, Ethiopia \\ Email: nassiroub@gmail.com
}

Received 26 May 2016; accepted 25 July 2016; published 28 July 2016

Copyright (C) 2016 by author and Scientific Research Publishing Inc.

This work is licensed under the Creative Commons Attribution International License (CC BY).

http://creativecommons.org/licenses/by/4.0/

(c) (1) Open Access

\section{Abstract}

This paper analyses the greenhouse gas (GHG) emission along the value chains of two strategic commodities in West Africa (rice and maize) in four pilot countries: Ghana, Senegal Benin and Cote D'Ivoire. The Value Chains Analysis and Greenhouse model used in this study, provides insight into the relationship between output maximization and GHG emissions to help define optimal intervention approaches that minimize emissions while maximizing the potential yield, hence boost food security. It highlights intervention measures for improvement of production and productivity along with the identification of mitigation measures to reduce GHG emissions. It also revealed that the largest GHG emission factor from maize farming in the selected countries is from the application of nitrogen fertilizers $\left(\mathrm{NO}_{2}\right)$, and for rice farming, depending on the systems, e.g. rain fed, irrigated or multiple aeration, the emission is mostly due to anaerobic decomposition of methane $\left(\mathrm{CH}_{4}\right)$ which increases with flooding practice.

\section{Keywords}

Value Chains, Greenhouse Gas Emission, Output Maximization, Food Security

\section{Background}

Agriculture is the primary sector of almost any African economy. About $65 \%$ of the total labor force is employed in the agriculture sector, which contributes about 32\% of the continent's gross domestic product (GDP). 
The sector has remained the backbone of Africa's economic development for centuries without having taken on a real structural transformation. This lack of transformation perpetuates the characterization of Africa as a cheap and secure source of primary commodities required to feed the growing needs and changing demands of the traditionally established and newly emerging industrial super-economies. In line with both Abuja High Level Conference on Agribusiness and Agro industries and the Malabo Declarations, which respectively 1) urged the African Union AU member states not only to establish the requisite legal, regulatory and institutional frameworks to support agribusiness and agro-industry development, but also to put in place programs to accelerate the development of the value of strategic food commodities; and 2) committed to halving poverty by the year 2025 through inclusive agricultural growth and transformation. As such the heads of state committed to ensure that the agricultural growth, to sustain annual agricultural GDP growth of at least $6 \%$, to establish and/or strengthen inclusive public private partnerships for at least five priority agricultural commodity value chains with strong linkage to smallholder agriculture. It is with this background and within the Comprehensive Africa Agriculture Development Programme (CAADP) new framework that the United Nations Economic Commission for Africa (UNECA), in collaboration with the African Union Commission (AUC), the Food and Agriculture Organization (FAO), and Economic Community of West African States (ECOWAS), has launched an initiative for the development of strategic commodities regional value chains in Africa. As no agricultural development initiative should look away from climate change issues, UNECA decided to analyse the Greenhouse Gas emission along the value chains, which is a factor most often overlooked. The Value Chain Analysis-Greenhouse Gas (VCA-GHG) model implemented for this study provides insight into the relationship between output maximization and greenhouse gas (GHG) emissions to help define optimal intervention approaches that minimize GHG emissions while maximizing the potential economic yield.

\section{Purpose of the Study}

The study will assist the governments of four ECOWAS countries with using the climate change aspects of a value chain assessment to inform possible interventions. Specifically, an assessment of GHG using a value chain analysis (VCA) approach will examine the feasibility of integrating a low-carbon path and adaptation strategies into plans for agriculture sector growth.

\section{Objectives of the Study}

The primary objective of the value chain-based GHG emission analysis is to introduce a comprehensive analysis tool not only to identify constraints to increasing production along a product value chain, but at the same time to measure GHG emissions along that same value chain to determine the most appropriate intervention that maximizes output while minimizing GHG emissions. This analysis is expected to provide insights into the relationship between output maximization and GHG emissions to help define optimal intervention approaches that minimize GHG emissions while maximizing the potential yield rate for selected strategic agro-commodity products. The specific objectives of the study are to 1) assess the current situation of rice and maize production and the corresponding levels of GHG emissions; and 2) define potential solutions to greenhouse gas emission.

\section{Expected Outcome}

The paper is intended to raise the awareness of policy makers on the urgency to take greenhouse gas emissions into account while trying to maximize yield of agricultural production. In this context, reduction of GHG emission is seen as a pathway to positively factor climate change into food crop production while mitigating emissions throughout the value chains of the selected commodities and thereby ensure the sustainability and reduced vulnerability of the agricultural sector.

\section{Study Scope and Components}

The major on-farm activities (value chain stages and related GHG emissions) considered in analyzing rice and maize farming in this study are: Nursery; land preparation; sowing/transplanting; cultivation; harvesting; threshing; and drying. Based on the nature of farm activities, the scope of GHG emissions analyzed encompasses $\mathrm{CO}_{2}, \mathrm{CH}_{4}$ and $\mathrm{N}_{2} \mathrm{O}$; other types of greenhouse gases, such as halogenated gases, are not emitted from farming processes. Furthermore, though black carbon was recently recognized as a contributor to global warm- 
ing, the VCA-based GHG emission tool does not consider it for analysis due to lack of country-specific and Intergovernmental Panel on Climate Change (IPCC) default emission factors that deal with black carbon created through residue burning on rice farms. This study does not consider issues related to: production/manufacturing of input materials (fertilizers, seed varieties, pesticides, etc.); the GHG impact of spraying (e.g., pesticide, herbicide, fungicide, growth enhancer) is limited to the diesel and/or benzene used to power a mechanical sprayer and the transport of such products, if applicable. Though the effects of such sprayed products may or may not be otherwise deleterious to general environmental health, the sprayed products themselves do not emit $\mathrm{GHG}^{1}$. It is important to note that the observations made and the conclusions drawn in this paper are based on interviews with selected farmers in key rice and maize producing areas in the countries. In this context, the various farming methods practiced in these areas are taken into consideration in the analysis to help develop a profile of representative farming practices and associated value chains and corresponding GHG emissions. It also is important to note that the study of the representative farms in each region takes a "whole farm" approach, and as such, identifies all sources of value, cost and GHG emissions that occur within the farm-gate related to the production of rice or maize.

\section{Methodology: Value Chain Based-GHG Emissions Reduction Approach}

The methodology utilized here is from Global Development Solutions, LLC (GDS) proprietary integrated value chain analysis (IVCA) methodology to identify constraints along the value chains of rice and maize to help define optimal intervention points and activities to increase production. At the same time, GDS transposed onto the IVCA an additional tool to measure GHG emissions along the same value chain. This provides insights into the relationship between output maximization and GHG emissions to help define optimal intervention approaches that minimize GHG emissions while maximizing the potential yield rate for rice and maize.

\section{Executive Summary}

In Ghana, GHG emissions are found to be $1.7 \mathrm{t} \mathrm{CO}_{2} \mathrm{e} / \mathrm{ha}$ or $1.11 \mathrm{t} \mathrm{CO}_{2} \mathrm{e} /$ ton paddy for rain-fed rice farms, whereas they are $4.79 \mathrm{t} \mathrm{CO}_{2} \mathrm{e} / \mathrm{ha}$ or $2.84 \mathrm{t} \mathrm{CO}_{2} \mathrm{e} /$ ton paddy for continuously flooded farms, $4.04 \mathrm{t} \mathrm{CO}_{2} \mathrm{e} / \mathrm{ha}$ or $1.25 \mathrm{t}$ $\mathrm{CO}_{2} \mathrm{e} /$ ton paddy for single aerated and $3.89 \mathrm{t} \mathrm{CO}_{2} \mathrm{e} / \mathrm{ha}$ or $1.15 \mathrm{t} \mathrm{CO}_{2} \mathrm{e} /$ ton paddy for multiple aerated rice farms. Continuously flooded farms have higher GHG emissions due to methane generation arising from anaerobic decomposition and higher rates of fertilizer application compared to rain-fed rice farms. In Senegal: GHG emissions are $1.85 \mathrm{t} \mathrm{CO}_{2} \mathrm{e} / \mathrm{ha}$ or $0.6 \mathrm{t} \mathrm{CO}_{2} \mathrm{e} /$ ton paddy for rain-fed rice farms. Emissions from irrigated (multiple aerated) farms are $4.02 \mathrm{t} \mathrm{CO}_{2} \mathrm{e} / \mathrm{ha}$ or $0.84 \mathrm{t} \mathrm{CO}_{2} \mathrm{e} /$ ton paddy. Irrigated farms have higher GHG emissions due to methane generation arising from anaerobic decomposition and the higher rate of fertilizer application compared to the rain-fed rice farms. In Cote D'Ivoire, The main source of GHG emissions is fertilizer application which contributes $87.5 \%$ of the total emissions in maize farming $\left(0.64 \mathrm{t} \mathrm{CO}_{2} \mathrm{e} / \mathrm{ha} / \mathrm{season}\right)$. Out of this, application of nitrogen fertilizers contributes $89.3 \%$ due to the release of $\mathrm{N}_{2} \mathrm{O}$. In Benin, the main source of GHG emissions is fertilizer application which contributes $87 \%$ of the total emissions in maize farming $\left(0.4 \mathrm{t} \mathrm{CO}_{2} \mathrm{e} / \mathrm{ha} / \mathrm{season}\right)$. Out of this, application of nitrogen fertilizers contributes $90 \%$ due to the release of $\mathrm{N}_{2} \mathrm{O}$. The total of all emissions from maize farming is 0.46 tons of $\mathrm{CO}_{2}$ equivalent per hectare $\left(\mathrm{t} \mathrm{CO}_{2} \mathrm{e} / \mathrm{ha}\right)$.

\section{Country Case Studies}

\subsection{Case of Ghana: Rice}

\subsubsection{Value Chain of Analysis: (VCA)}

Ghana's per capita rice consumption rate is $38 \mathrm{~kg}$ per annum for its 22 million population. The national rice production covers about $36 \%$ of the nation's consumption (more than 975,000 tons of milled rice [1] and the country imports the balance to meet the total national demand. Since 2009, when milled rice production was only 235,000 tons [1] the annual rate of increase in rice consumption (15\%) is moving at par with the annual increase in rate of production (15\%). Countering the shortfall between production and consumption, the rate of milled rice import has been increasing at a rate of about 14\% during the period 2009 to 2013.

In rain-fed farming in Ghana, the VCA study revealed that the leading cost contributors to rain-fed rice

\footnotetext{
${ }^{1}$ Although there is no GHG impact from sprayed products, there is a VCA impact. For example, poor quality sprayers result in excess chemical use and inefficiencies in application (both drivers of cost) as well as create potential health hazards.
} 
farming are cultivation (34.2\% of the total cost), planting (29.1\%) and harvesting (21.1\%). In Irrigated Rice Farming (Continuous flooding), the VCA study revealed that the leading cost contributors are cultivation (33.1\% of cost), harvesting (23.1\%) and administration and overheads (18.8\%). In irrigated Rice Farming (Single aeration), the VCA revealed that the leading cost contributors are cultivation (59.5\% of cost), harvesting (16.3\%), and land preparation (10.1\%). In irrigated Rice Farming (Multiple aeration), the VCA study revealed that the leading cost contributors are cultivation (66.7\% of cost), land preparation (13.3\%) and harvesting (10.6\%).

\subsubsection{GHG Emission Analysis and Discussion}

The analysis of VCA-GHG for rice farming conducted for Ghana indicates that the average yield is $2.3 \mathrm{t}$ paddy/ ha/season for rain-fed, $1.82 \mathrm{t}$ paddy/ha/season for continuously flooded, $3.42 \mathrm{t}$ paddy/ha/season for single aerated and $3.95 \mathrm{t}$ paddy/ha/season for multiple aerated rice farms. The cost of production is GHC 1063 (USD 367)/ha for rain-fed, GHC 1550 (USD 536)/ha for continuously flooded, GHC 1894 (USD 655)/ha for single aerated and GHC 1689 (USD 584)/ha for multiple aerated rice farms. The production costs per unit area and unit product for continuously flooded farms are higher due to lower productivity compared to the rain-fed, single aerated and multiple aerated farms.

In Table 1, GHG emissions are $1.7 \mathrm{t} \mathrm{CO}_{2} \mathrm{e} / \mathrm{ha}$ or $1.11 \mathrm{t} \mathrm{CO}_{2} \mathrm{e} /$ ton paddy for rain-fed rice farms, whereas they are $4.79 \mathrm{t} \mathrm{CO}_{2} \mathrm{e} /$ ha or $2.84 \mathrm{t} \mathrm{CO}_{2} \mathrm{e} /$ ton paddy for continuously flooded farms, $4.04 \mathrm{t} \mathrm{CO}_{2} \mathrm{e} /$ ha or $1.25 \mathrm{t} \mathrm{CO}_{2} \mathrm{e} / \mathrm{ton}$ paddy for single aerated and $3.89 \mathrm{t} \mathrm{CO}_{2} \mathrm{e} / \mathrm{ha}$ or $1.15 \mathrm{t} \mathrm{CO}_{2} \mathrm{e} /$ ton paddy for multiple aerated rice farms. Continuously flooded farms have higher GHG emissions due to methane generation arising from anaerobic decomposition and higher rates of fertilizer application compared to rain-fed rice farms. Yet, continuously flooded farms post lower paddy yields than rain-fed farms, thus creating the bad combination of higher GHG emissions and lower yields. Both single and multiple aerated farms have lower methane emissions due to aeration even though they apply higher rates of fertilizer compared to the continuously flooded rice farms. They also both yield more abundantly than continuously flooded and rain-fed systems and thus exhibit the preferred combination of lower GHG emissions and higher yields.

Farmers apply NPK (15-15-15, 23-10-0, or 23-10-5) and urea (46\% N) at an average rate of $394.14 \mathrm{~kg} / \mathrm{ha}$ and $227.96 \mathrm{~kg} / \mathrm{ha}$, respectively, whereas the recommended application rates for Ghana are $373 \mathrm{~kg} / \mathrm{ha}$ for NPK (spe-

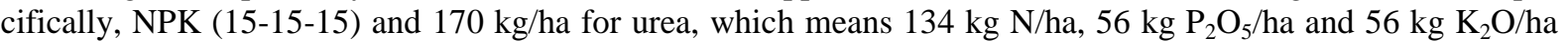
for land under continuous use and hybrid seed application [2]. This shows that farmers using urea and NPK are applying more than the recommended rates (163 kg N/ha, $59 \mathrm{~kg}_{2} \mathrm{O}_{5} / \mathrm{ha}$ and $59 \mathrm{~kg} \mathrm{~K} \mathrm{O} / \mathrm{ha}$ ). The relatively higher average yield these farms achieved $(2694 \mathrm{~kg} / \mathrm{ha})$, however, cannot be justified compared to a potential yield of 4.5 ton/ha achieved by some interviewed farmers.

In Table 2, anaerobic decomposition gives the high emission rate in all 4 rice farming system observed above with fertilizing coming second and residue burning and fuel consumption being third and last.

The next major contributor to GHG emissions is the application of fertilizer; $0.72 \mathrm{t} \mathrm{CO}_{2} \mathrm{e} / \mathrm{ha} / \mathrm{season}$ for continuously flooded and $0.33 \mathrm{t} \mathrm{CO}_{2} \mathrm{e} /$ ha/season for rain-fed rice fields in Ghana. Likewise, the GHG emissions from single and multiple aerated fields arising from fertilizer application are $0.81 \mathrm{t} \mathrm{CO}_{2} \mathrm{e} / \mathrm{ha} /$ season for each. Though not very significant, GHG emissions that arise from residue burning and fuel combustion contribute $0.13 \mathrm{t} \mathrm{CO}_{2} \mathrm{e} / \mathrm{ha} / \mathrm{season}$ and $0.79 \mathrm{t} \mathrm{CO}_{2} \mathrm{e} / \mathrm{ha} /$ season for rain-fed and continuous flooded fields, respectively. In a similar manner, emissions from residue burning and fuel combustion are $0.91 \mathrm{t} \mathrm{CO}_{2} \mathrm{e} / \mathrm{ha} /$ season and $0.87 \mathrm{t}$

Table 1. Summary of findings for rain-fed and continuously flooded rice farms in Ghana.

\begin{tabular}{|c|c|c|c|c|c|c|c|c|}
\hline RICE-Ghana & $\begin{array}{c}\text { Rain } \\
\text { fed }\end{array}$ & (US\$/unit) & $\begin{array}{l}\text { Continuous } \\
\text { flooding }\end{array}$ & (US\$/unit) & $\begin{array}{c}\text { Single } \\
\text { aeration }\end{array}$ & (US\$/unit) & $\begin{array}{l}\text { Multiple } \\
\text { aeration }\end{array}$ & (US\$/unit) \\
\hline Yield rate (t/ha) & 2.3 & & 1.82 & & 3.42 & & 3.95 & \\
\hline Cost per hectare (GHC/ha) & 1063 & 367 & 1550 & 536 & 1894 & 655 & 1689 & 584 \\
\hline $\begin{array}{l}\text { Cost per production unit } \\
\text { (GHC/ton paddy) }\end{array}$ & 516 & 178 & 886 & 306 & 553 & 191 & 487 & 168 \\
\hline $\begin{array}{l}\text { Emissions rate per hectare } \\
\left.\text { (t } \mathrm{CO}_{2} \mathrm{e} / \mathrm{ha}\right)\end{array}$ & 1.7 & & 4.79 & & 4.04 & & 3.89 & \\
\hline $\begin{array}{l}\text { Emissions per production unit } \\
\left.\text { (t } \mathrm{CO}_{2} \mathrm{e} / \text { ton paddy }\right)\end{array}$ & 1.11 & & 2.84 & & 1.25 & & 1.15 & \\
\hline
\end{tabular}

Source: Global Development Solutions, LLC.

${ }^{2} \mathrm{GHC}$ is the local currency of Ghana. It's called Ghana CD. 
Table 2. Emission sources from rice farming systems.

\begin{tabular}{|c|c|c|c|c|c|}
\hline \multicolumn{6}{|c|}{ Emission sources } \\
\hline Rain fed & $\mathrm{CO}_{2}(\mathrm{t} \mathrm{CO} 2 \mathrm{e} / \mathrm{ha})$ & $\mathrm{CH}_{4}(\mathrm{t} \mathrm{CO} 2 \mathrm{e} / \mathrm{ha})$ & $\mathrm{N} 20$ (t CO $2 \mathrm{e} / \mathrm{ha})$ & Total (t CO $2 \mathrm{e} / \mathrm{ha})$ & Total (\%) \\
\hline Anaerobic decomposition & & 1.23 & & 1.23 & 72.5 \\
\hline Fertilizing (all stages) & 0.02 & & 0.31 & 0.33 & 19.6 \\
\hline Residue burning & & 0.04 & 0.02 & 0.06 & 3.6 \\
\hline Fuel consumption & 0.07 & & 0 & 0.07 & 4.4 \\
\hline Total & 0.09 & 1.27 & 0.33 & 1.7 & 100.1 \\
\hline Total (\%) & 5.6 & 75.1 & 19.3 & & \\
\hline \multicolumn{6}{|c|}{ Continuous flooding } \\
\hline Anaerobic decomposition & & 3.28 & & 3.28 & 68.5 \\
\hline Fertilizing (all stages) & 0.07 & & 0.64 & 0.72 & 15 \\
\hline Residue burning & & 0.08 & 0.03 & 0.12 & 2.5 \\
\hline Fuel consumption & 0.67 & & 0.01 & 0.67 & 14.1 \\
\hline Total & 0.74 & 3.36 & 0.68 & 4.79 & 100.1 \\
\hline Total (\%) & 15.5 & 70.2 & 14.2 & & \\
\hline \multicolumn{6}{|c|}{ Single aeration } \\
\hline Anaerobic decomposition & & 2.32 & & 2.32 & 57.4 \\
\hline Fertilizing (all stages) & 0.07 & & 0.74 & 0.81 & 20.2 \\
\hline Residue burning & & 0.11 & 0.04 & 0.16 & 4 \\
\hline Fuel consumption & 0.75 & & 0.01 & 0.75 & 18.6 \\
\hline Total & 0.82 & 2.43 & 0.79 & 4.04 & 100.1 \\
\hline Total (\%) & 20.2 & 60.2 & 19.6 & & \\
\hline \multicolumn{6}{|c|}{ Multiple aeration } \\
\hline Anaerobic decomposition & & 2.41 & & 2.41 & 62 \\
\hline Fertilizing (all stages) & 0.06 & & 0.75 & 0.81 & 20.8 \\
\hline Residue burning & & 0.1 & 0.04 & 0.14 & 3.7 \\
\hline Fuel consumption & 0.52 & & 0 & 0.53 & 13.5 \\
\hline Total & 0.58 & 2.52 & 0.79 & 3.89 & 100 \\
\hline Total (\%) & 14.9 & 64.7 & 20.4 & & \\
\hline
\end{tabular}

Source: Global Development Solutions, LLC.

$\mathrm{CO}_{2} \mathrm{e} / \mathrm{ha} / \mathrm{season}$ for single and multiple aerated rice fields. The overall GHG emissions from rice farms in Ghana are $1.7 \mathrm{t} \mathrm{CO}_{2} \mathrm{e} / \mathrm{ha} /$ season for rain-fed farms and $4.79 \mathrm{t} \mathrm{CO}_{2} \mathrm{e} / \mathrm{ha} /$ season for continuously flooded farms, $4.04 \mathrm{t}$ $\mathrm{CO}_{2} \mathrm{e} / \mathrm{ha}$ /season for single and $3.89 \mathrm{t} \mathrm{CO}_{2} \mathrm{e} / \mathrm{ha} /$ season for multiple aerated fields (Table 2). Generally, even though the GHG emissions per hectare estimated for Ghana are equivalent to emission rates in other countries, the emissions per unit of product are higher due to the low yield rate. For example, for continuously flooded rice farms the emission per unit of product is $2.84 \mathrm{t} \mathrm{CO}_{2} \mathrm{e} / \mathrm{t}$ paddy in Ghana while it is $1.08 \mathrm{t} \mathrm{CO}_{2} \mathrm{e} / \mathrm{t}$ paddy in Vietnam.

\subsection{Case of Senegal: Rice}

\subsubsection{Value Chain of Analysis: (VCA)}

Rice farming in Senegal can generally be categorized into rain-fed and irrigated rice farms. All irrigated farms 
participating in this study reported applied multiple aeration water management regimes during cultivation of rice. The value chain analysis and the greenhouse gas emissions will, therefore, be analyzed according to these two most prevalent water management systems. Reduction of post-harvest losses is a big challenge to be tackled in Senegal where post-harvest losses at all stages of the post-harvest activities amounts to 35\% [3].

Rain-fed rice: The VCA study revealed that the leading cost contributors to rain-fed rice farming in Senegal are harvesting and land preparation, each contributing $27 \%$ to the total cost of production. Cultivation is the third major cost contributor with $22 \%$ but with planting contributing nearly the same to overall costs (21\%). Irrigated rice: The VCA study revealed that the leading cost contributors are cultivation (39\% of cost), harvesting (32\%) and land preparation (12\%). Fertilizing contributes 54\% to the cost of cultivation, of which $57 \%$ is attributable to the cost of urea and $42 \%$ for NPK, with the remaining $1 \%$ for labor.

\subsubsection{GHG Emission Analysis and Discussion}

According to the VCA-GHG study, the methane emissions from multiple aerated rice fields are about $1.81 \mathrm{t}$ $\mathrm{CO}_{2} \mathrm{e} / \mathrm{ha} /$ season, and approximately $1.03 \mathrm{t} \mathrm{CO}_{2} \mathrm{e} / \mathrm{ha} /$ season for rain-fed rice fields. The emission results for multiple aerated fields are comparable to rice fields under similar conditions in other rice producing countries such as Vietnam, specifically with rice fields that do not apply manure during land preparation and use multiple aeration $\left(2.37 \mathrm{t} \mathrm{CO}_{2} \mathrm{e} / \mathrm{ha} / \mathrm{season}\right)$.

The next major contributor to GHG emissions is the application of fertilizer at $1.75 \mathrm{t} \mathrm{CO}_{2} \mathrm{e} /$ ha/season for multiple aerated fields and $0.49 \mathrm{t} \mathrm{CO}_{2} \mathrm{e} / \mathrm{ha} /$ season for rain-fed rice fields in Senegal. Based on the sample survey, there is no emission from residue burning as it is not practiced in Senegal. GHG emissions that arise from fuel combustion contribute $0.42 \mathrm{t} \mathrm{CO}_{2} \mathrm{e} / \mathrm{ha} /$ season and $0.45 \mathrm{t} \mathrm{CO}_{2} \mathrm{e} / \mathrm{ha} /$ season for rain-fed and irrigated fields, respectively, due to the fact that tractors are used for tilling in both systems. The overall GHG emissions from rice farms in Senegal are about $1.94 \mathrm{t} \mathrm{CO}_{2} \mathrm{e} / \mathrm{ha} /$ season for rain-fed farms and $4.02 \mathrm{t} \mathrm{CO}_{2} \mathrm{e} / \mathrm{ha} /$ season for multiple aerated farms. Demand for rice is increasing at the rate of $2 \%$ every year.

In Table 3, according to the VCA-GHG study, the methane emissions from multiple aerated rice fields are about $1.81 \mathrm{t} \mathrm{CO}_{2} \mathrm{e} / \mathrm{ha} /$ season, and approximately $1.03 \mathrm{t} \mathrm{CO}_{2} \mathrm{e} / \mathrm{ha} /$ season for rain-fed rice fields in Senegal. The emission results for multiple aerated fields are comparable to rice fields under similar conditions in other rice producing

Table3. GHG emissions along the VCA of rice production in Senegal.

\begin{tabular}{|c|c|c|c|c|c|}
\hline \multicolumn{6}{|c|}{ Emission sources } \\
\hline Rain fed & $\mathrm{CO}_{2}(\mathrm{t} \mathrm{CO} 2 \mathrm{e} / \mathrm{ha})$ & $\mathrm{CH}_{4}(\mathrm{t} \mathrm{CO} 2 \mathrm{e} / \mathrm{ha})$ & $\mathrm{N}_{2} \mathrm{O}\left(\mathrm{t} \mathrm{CO} \mathrm{CO}_{2} \mathrm{e} / \mathrm{ha}\right)$ & Total (t CO $2 \mathrm{e} / \mathrm{ha})$ & Total (\%) \\
\hline Anaerobic decomposition & 0 & 1.03 & 0 & 1.03 & 53.1 \\
\hline Fertilizing (all stages) & 0.05 & & 0.45 & 0.49 & 25.4 \\
\hline Residue burning & & 0 & 0 & 0 & 0 \\
\hline Fuel consumption & 0.42 & & 0 & 0.42 & 21.6 \\
\hline Total & 0.46 & 1.03 & 0.45 & 1.94 & 100 \\
\hline Total (\%) & 24 & 53.1 & 23.1 & & \\
\hline \multicolumn{6}{|l|}{ Irrigated (multiple aeration) } \\
\hline Anaerobic decomposition & 0 & 1.81 & 0 & 1.81 & 45.1 \\
\hline Fertilizing (all stages) & 0.2 & & 1.55 & 1.75 & 43.5 \\
\hline Residue burning & & 0 & 0 & 0 & 0 \\
\hline Fuel consumption & 0.45 & & 0 & 0.45 & 11.3 \\
\hline Total & 0.65 & 1.81 & 1.55 & 4.02 & 100 \\
\hline Total (\%) & 16.2 & 45.1 & 38.6 & & \\
\hline
\end{tabular}

Source: Global Development Solutions, LLC/UNECA (2013). 
countries such as Vietnam, specifically with rice fields that do not apply manure during land preparation and use multiple aeration (2.37 t CO $2 \mathrm{e} / \mathrm{ha} /$ season).

The next major contributor to GHG emissions is the application of fertilizer at $1.75 \mathrm{t} \mathrm{CO}_{2} \mathrm{e} /$ ha/season for multiple aerated fields and $0.49 \mathrm{t} \mathrm{CO}_{2} \mathrm{e} / \mathrm{ha} / \mathrm{season}$ for rain-fed rice fields in Senegal. Based on the sample survey, there is no emission from residue burning as it is not practiced in Senegal. GHG emissions that arise from fuel combustion contribute $0.42 \mathrm{t} \mathrm{CO}_{2} \mathrm{e} / \mathrm{ha} /$ season and $0.45 \mathrm{t} \mathrm{CO}_{2} \mathrm{e} / \mathrm{ha} /$ season for rain-fed and irrigated fields, respectively, due to the fact that tractors are used for tilling in both systems. The overall GHG emissions from rice farms in Senegal are about $1.94 \mathrm{t} \mathrm{CO}_{2} \mathrm{e} / \mathrm{ha} /$ season for rain-fed farms and $4.02 \mathrm{t} \mathrm{CO}_{2} \mathrm{e} / \mathrm{ha} / \mathrm{season}$ for multiple aerated farms (Table 3). Generally, even though the GHG emissions per hectare estimated for Senegal are equivalent to emission rates in other countries, the emissions per unit of production are higher due to the lower yield rate. For example, for multiple aerated rice farms the emission per ton produced is $0.84 \mathrm{t} \mathrm{CO}_{2} \mathrm{e} /$ ton paddy in Senegal while it is $0.5 \mathrm{t} \mathrm{CO}_{2} \mathrm{e} /$ ton paddy in Vietnam.

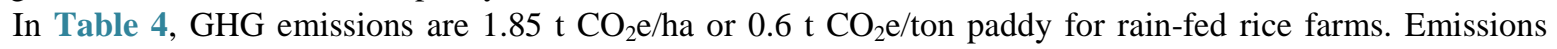
from irrigated (multiple aerated) farms are $4.02 \mathrm{t} \mathrm{CO}_{2} \mathrm{e} /$ ha or $0.84 \mathrm{t} \mathrm{CO}_{2} \mathrm{e} /$ ton paddy. Irrigated farms have higher GHG emissions due to methane generation arising from anaerobic decomposition and the higher rate of fertilizer application compared to the rain-fed rice farms.

\subsection{Case of Cote D'Ivoire: Maize}

In Table 5, based on the analysis, the total cost of production per hectare of maize is $\mathrm{XOF}^{3}$ 149, 269 (US\$ 305)/ton. Out of this cost, fertilizer accounts for $40 \%$ followed by human labor cost (22.5\%) and the cost of agricultural

Table 4. Summary of findings for rain-fed and irrigated rice farms in Senegal.

\begin{tabular}{ccccc}
\hline Farm production & Rain fed & (US\$/unit) & Irrigated (multiple aeration) & (US\$/unit) \\
\hline Yield rate (t/ha) & 3.14 & & 4.77 \\
Cost per hectare (XOF/ha) & 164,818 & 336 & 403,958 & 824 \\
Cost per production unit (XOF/ton paddy) & 62,447 & 127 & 99,304 & 4.02 \\
Emissions rate per hectare (t CO $2 \mathrm{e} / \mathrm{ha})$ & 1.85 & & 0.84 \\
Emissions per production unit (t CO $2 \mathrm{e} /$ ton paddy) & 0.6 & & \\
\hline
\end{tabular}

Source: Global Development Solutions, LLC/UNECA (2013).

Table 5. Performance and costs of rain-fed maize farms.

\begin{tabular}{|c|c|c|c|}
\hline Cost & Total (XOF/ha) & (US\$/ha) & Total (\%) \\
\hline Hired human labor (all stages) & 33,608 & 68.6 & 22.52 \\
\hline Hired animal labor (all stages) & 2800 & 5.7 & 1.88 \\
\hline Seed & 4325 & 8.8 & 2.90 \\
\hline Tilling, excluding labor & 4250 & 8.7 & 2.85 \\
\hline Fertilizer (all stages) & 59,450 & 121.3 & 39.83 \\
\hline Agriculture chemicals including equip. (all stages) & 23,655 & 48.3 & 15.85 \\
\hline Harvesting, excluding labor & 14,899 & 30.4 & 9.98 \\
\hline Admin and Overhead & 6282 & 12.8 & 4.21 \\
\hline Total & 149,269 & 304.6 & 100.00 \\
\hline Cost per production unit (XOF (US\$)/ton) & 60,616 & 123.7 & \\
\hline Yield rate (t/ha) & & 2.74 & \\
\hline
\end{tabular}

Source: Global Development Solutions, LLC/UNECA (2013).

${ }^{3}$ XOF is a local currency in Former French Colonised West African Countries including Senegal, Cote D’Ivoire and Benin. 
chemicals (15.8\%). The average yield of maize for smallholder and cooperative farms is about $2.74 \mathrm{t} / \mathrm{ha}$. The cost per unit of product is XOF 60,616 (US\$123.7)/t.

The second biggest cost in maize farming is related to hired human labour which amounts to XOF 33,608 (US\$ 68.6)/ha. The total average level of effort per farm is equivalent to 16 man-days/ha/season for all maize farming activities along the value chain in Côte d'Ivoire. Representing one-third of all hired labor activities, labor for land preparation requires the highest level of effort. Planting, the second highest labor burden with a 14.4\% overall contribution, requires less than half the effort of land preparation. Planting is followed closely by threshing (13.1\%), weeding (12.4\%) and harvesting (12.3\%).

In Table 6, the main source of GHG emissions is fertilizer application which contributes $87.5 \%$ of the total emissions in maize farming $\left(0.64 \mathrm{t} \mathrm{CO}_{2} \mathrm{e} / \mathrm{ha} /\right.$ season$)$. Out of this, application of nitrogen fertilizers contributes 89.3\% due to the release of $\mathrm{N}_{2} \mathrm{O}$.

In Table 7 bellow, the GHG emission rate in Côte d'Ivoire would have been higher if the nationally recommended fertilizer application were practiced. The GHG emissions from fertilizer application would have increased by $62.5 \%$ from $0.56 \mathrm{t} \mathrm{CO}_{2} \mathrm{e} /$ ha/season to $0.91 \mathrm{t} \mathrm{CO}_{2} \mathrm{e} / \mathrm{ha} /$ season as shown in Table 7.

As can be observed from the above tables, the largest GHG emission from maize farming is $\mathrm{N}_{2} \mathrm{O}$ from the application of nitrogen fertilizers. Though insignificant, emissions from burning fuel to operate farm machinery and equipment as well as residue burning contribute $7.8 \%$ and $4.7 \%$ respectively. This low level of emissions from fuel burning reflects the limited use of mechanization in Côte d'Ivoire. In the United States where maize farms are more highly mechanized, by contrast, GHG emissions from fuel combustion represent $15.4 \%$ of total maize farming emissions [4].

During the field visit, no interviewed farmers applied lime to their field. Literature indicates that soils in the humid zone of Côte d'Ivoire are highly acidic (up to $4.9 \mathrm{pH}$ ) which even allowed direct application of phosphate rock with some positive responses [5] Continuous application of urea decreases the $\mathrm{pH}$ of the soil and thereby exacerbates acidity of the soil. Neutral soil $\mathrm{pH}$ is more favorable for rice production. The most important nutrients are available for plant growth in soils with a pH of 5 to 9 in general, and in the $\mathrm{pH}$ range of 6.5 - 7 typical of many submerged soils in which rice grows [6]. It is, therefore, suggested that soil profiling is required to ensure a balanced $\mathrm{pH}$ to help optimize fertilizer application.

Moreover, rice farmers do not apply manure to improve the fertility of the soil. However, $15.4 \%$ of the interviewed farms incorporate rice residue into the soil during land preparation which contributes to increasing the organic content of the soil. Unfortunately, 53.8\% of farmers remove the residue and 30.8\% burn it elsewhere.

Table 6. GHG emissions along the maize production value chain.

\begin{tabular}{|c|c|c|c|c|c|}
\hline Emission sources & $\mathrm{CO}_{2}\left(\mathrm{t} \mathrm{CO}{ }_{2} \mathrm{e} / \mathrm{ha}\right)$ & $\mathrm{CH}_{4}\left(\mathrm{t} \mathrm{CO}{ }_{2} \mathrm{e} / \mathrm{ha}\right)$ & $\mathrm{N}_{2} \mathrm{O}\left(\mathrm{t} \mathrm{CO}{ }_{2} \mathrm{e} / \mathrm{ha}\right)$ & Total (t CO $2 \mathrm{e} / \mathrm{ha})$ & Total (\%) \\
\hline Fertilizer (all stages) & 0.06 & & 0.5 & 0.56 & 87.5 \\
\hline Residue burning & & 0.02 & 0.01 & 0.03 & 4.7 \\
\hline Fuel consumption & 0.05 & & 0.0 & 0.05 & 7.8 \\
\hline Total & 0.11 & 0.02 & 0.51 & 0.64 & 100 \\
\hline Total (\%) & 17.5 & 3.2 & 79.4 & & \\
\hline
\end{tabular}

Source: Global Development Solutions, LLC/UNECA (2013).

Table 7. GHG emissions from fertilizer application at the recommended rate.

\begin{tabular}{|c|c|c|c|c|c|}
\hline \multirow{2}{*}{ Fertilizer (all stages) } & Recommended quantity applied & $\mathrm{CO}_{2}$ & $\mathbf{N}_{2} \mathbf{O}$ & Total Emission & \multirow{2}{*}{$\%$} \\
\hline & kg/ha & t CO 2 e/ha & t CO $2 \mathrm{e} / \mathrm{ha}$ & t $\mathrm{CO}_{2} \mathrm{e} / \mathrm{ha}$ & \\
\hline Urea & 100 & 0.07 & 0.56 & 0.63 & 69.80 \\
\hline NPK & 150 & 0.00 & 0.27 & 0.27 & 30.20 \\
\hline Total & & 0.07 & 0.83 & 0.91 & 100.00 \\
\hline$\%$ & & 8.09 & 91.91 & & \\
\hline
\end{tabular}

Source: Global Development Solutions, LLC/UNECA (2013). 


\section{Summary of Findings}

The VCA-GHG study on maize farming conducted for Côte d'Ivoire indicates that the average yield is 2.74 t/ha/season. The average cost of production is XOF 149,269 (US\$ 305)/ha and the average unit cost of production is XOF 60,616 (US\$ 124)/t.

In Table 8, GHG emissions are $0.64 \mathrm{t} \mathrm{CO}_{2} \mathrm{e} /$ ha (or $0.29 \mathrm{t} \mathrm{CO}_{2} \mathrm{e} /$ ton) for maize farms. The major contributor to GHG emissions in maize farming is the application of fertilizers in general and the application of nitrogen fertilizers in particular due to high amount of $\mathrm{N}_{2} \mathrm{O}$ emission. GHG emissions due to fertilizer application are low in maize farming in Côte d'Ivoire compared the potential emissions from the application of the nationally recommended rate.

\subsection{Case of Benin: Maize}

\subsubsection{Value Chain of Analysis: (VCA)}

The summary of costs shows that the total cost of production per hectare of maize is XOF 126, 444 (USD 264). This cost is dominated by two inputs: hired human labor (52.5\%) and fertilizer (25.5\%). All other costs combined total only $22 \%$ of the overall cost. This again draws attention to the labor-intensive nature of maize farming in Benin. As a comparison, in Benin the average level of effort is 40.7 man-days per hectare whereas in Côte d'Ivoire the average is 32.7 man-days per hectare.

\subsubsection{GHG Emissions Analysis and Discussion}

The main source of GHG emissions is fertilizer application which contributes $87 \%$ of the total emissions in maize farming $\left(0.4 \mathrm{t} \mathrm{CO}_{2} \mathrm{e} / \mathrm{ha} / \mathrm{season}\right)$. Out of this, application of nitrogen fertilizers contributes $90 \%$ due to the release of $\mathrm{N}_{2} \mathrm{O}$. The total of all emissions from maize farming is 0.46 tons of $\mathrm{CO}_{2}$ equivalent per hectare (t $\mathrm{CO}_{2} \mathrm{e} / \mathrm{ha}$ ).

The GHG emission rate in Benin would have been higher if the regionally recommended fertilizer application was practiced, up to a triple from the current rate of $0.46 \mathrm{t} \mathrm{CO}_{2} \mathrm{e} /$ ha/season shown in Table 9 , to $1.30 \mathrm{t} \mathrm{CO}_{2} \mathrm{e} / \mathrm{ha} / \mathrm{se}-$ as on as shown in Table 10.

As can be observed from the above tables, the largest GHG emission from maize farming is $\mathrm{N}_{2} \mathrm{O}$ from the application of nitrogen fertilizers. Though insignificant, emissions from burning fuel to operate farm machinery

Table 8. Summary of findings for rain-fed maize farms in Côte d'Ivoire.

\begin{tabular}{ccc}
\hline Rain fed & & (US\$/unit) \\
Yield rate (t/ha) & 2.74 & 305 \\
Cost per hectare (XOF/ha) & 149,269 & 124 \\
Cost per production unit (XOF/ton) & 60,616 & 0.64 \\
Emissions rate per hectare (t CO $2 \mathrm{e} / \mathrm{ha})$ & 0.29 \\
Emissions per production unit (t CO $2 \mathrm{e} / \mathrm{ton})$ & \\
\hline
\end{tabular}

Source: Global Development Solutions, LLC/UNECA (2013).

Table 9. Per hectare GHG emissions along the maize production value chain.

\begin{tabular}{|c|c|c|c|c|c|}
\hline Emissions source & $\mathrm{CO}_{2}(\mathrm{t} \mathrm{CO} 2 \mathrm{e} / \mathrm{ha})$ & $\mathrm{CH}_{4}(\mathrm{t} \mathrm{CO} 2 \mathrm{e} / \mathrm{ha})$ & $\mathrm{N}_{2} \mathrm{O}(\mathrm{t} \mathrm{CO} 2 \mathrm{e} / \mathrm{ha})$ & Total (t $\left.\mathrm{CO}_{2} \mathrm{e} / \mathrm{ha}\right)$ & Total (\%) \\
\hline Fertilizer (all stages) & 0.04 & & 0.36 & 0.40 & $87.0 \%$ \\
\hline Residue burning & & 0.02 & 0.01 & 0.02 & $4.3 \%$ \\
\hline Fuel consumption & 0.04 & & & 0.04 & $8.7 \%$ \\
\hline Total & 0.08 & 0.02 & 0.37 & 0.46 & $100.0 \%$ \\
\hline Total (\%) & $17.3 \%$ & $4.3 \%$ & $80.4 \%$ & & \\
\hline
\end{tabular}

Source: Global Development Solutions, LLC/UNECA (2013). 
and equipment as well as residue burning contribute $8.7 \%$ and $4.3 \%$ respectively. This low level of emissions from fuel burning reflects the limited use of mechanization in Benin. In the United States where maize farms are more highly mechanized, by contrast, GHG emissions from fuel combustion represent $15.4 \%$ of total maize farming emissions [7]. In comparing with Côte d'Ivoire, Benin emissions on a per hectare basis are $28.1 \%$ lower. However, due to the higher yields enjoyed in Côte d'Ivoire, the emission per ton in Benin are 31\% higher than in Côte d'Ivoire Table 11.

\subsubsection{Summary of Findings}

The VCA-GHG study on maize farming conducted for Benin indicates that the average yield is 1.36 tons/ha/season. The average cost of production is XOF 126,444 (USD 264.3)/ha, which translates to a production cost of XOF 109,055 (USD 227.9)/ton (Table 12).

Table 12 shows that, GHG emissions are $0.46 \mathrm{t} \mathrm{CO}_{2} \mathrm{e} / \mathrm{ha}$ (or $0.38 \mathrm{t} \mathrm{CO} \mathrm{C}_{2} \mathrm{e} / \mathrm{ton}$ ) for maize farms. The major contributor to GHG emissions in maize farming is the application of fertilizers, in general, and the application of nitrogen fertilizers, in particular, due to their high amount of $\mathrm{N}_{2} \mathrm{O}$ emissions. GHG emissions due to fertilizer application are low in maize farming in Benin compared to the potential emissions from the application at the regionally recommended rate.

\section{General Conclusion}

The results of the study showed that major source of GHG emission in rice farming in the two pilot countries is methane $\left(\mathrm{CH}_{4}\right)$ gas which arises from the anaerobic decomposition of biomass in soil under cover of water. As is evident from the name of the water management system, rice fields with continuous flooding stay under water during the cultivation period and thus emit more $\mathrm{CH}_{4}$ in comparison with rain-fed fields that are covered by water

Table 10. GHG emissions from fertilizer application at the recommended rate.

\begin{tabular}{|c|c|c|c|c|c|}
\hline Fertilizer (all stages) & Recommended quantity applied (kg/ha) & $\mathrm{CO}_{2}$ (t CO$\left.{ }_{2} \mathrm{e} / \mathrm{ha}\right)$ & $\mathrm{N}_{2} \mathrm{O}\left(\mathrm{t} \mathrm{CO} \mathrm{CO}_{2} \mathrm{e} / \mathrm{ha}\right)$ & Total emission ( $\left.\mathrm{C} \mathrm{CO}_{2} \mathrm{e} / \mathrm{ha}\right)$ & $(\%)$ \\
\hline Urea & 150 & 0.10 & 0.86 & 0.96 & $73.8 \%$ \\
\hline NPK & 200 & 0.00 & 0.34 & 0.34 & $26.2 \%$ \\
\hline Total & & 0.10 & 1.20 & 1.30 & $100.0 \%$ \\
\hline Total (\%) & & $7.7 \%$ & $92.3 \%$ & & \\
\hline
\end{tabular}

Source: Global Development Solutions, LLC/UNECA (2013).

Table 11. Comparing GHG emissions of Benin to Côte d'Ivoire.

\begin{tabular}{ccc}
\hline Countries & $\mathbf{C O}_{2} \mathbf{e} / \mathbf{h a}$ & $\mathbf{C O}_{2} \mathbf{e} / \mathbf{t o n}$ \\
\hline Benin & 0.46 & 0.38 \\
Côte D'Ivoire & 0.64 & 0.29 \\
\% Difference & $-28.10 \%$ & $31.00 \%$ \\
\hline
\end{tabular}

Source: Global Development Solutions, LLC/UNECA (2013).

Table 12. Summary of findings for rain-fed maize farms in Benin.

\begin{tabular}{cc} 
Yield rate (tons/ha) & 1.36 \\
Cost per hectare (XOF/ha) & 126,444 (USD264.3) \\
Cost per production unit (XOF/ton) & 109,055 (USD227.9) \\
Emissions rate per hectare (t CO $\left.\mathrm{C}_{2} \mathrm{e} / \mathrm{ha}\right)$ & 0.46 \\
Emissions rate per production unit $\left(\mathrm{t} \mathrm{CO}_{2} \mathrm{e} /\right.$ ton $)$ & 0.38 \\
\hline
\end{tabular}

Source: Global Development Solutions, LLC/UNECA (2013). 
for shorter periods. The emission results for continuously flooded fields are comparable to rice fields under similar conditions in other rice producing countries such as Vietnam, specifically with rice fields that do not apply manure during land preparation For maize farming, the study showed that the main source of GHG emissions is fertilizer application which contributes $87 \%$ of the total emissions in maize farming. Though not very significant, GHG emissions that arise from residue burning and fuel combustion contribute by $0.07 \mathrm{t} \mathrm{CO}_{2} \mathrm{e} / \mathrm{ha} / \mathrm{season}$ and $0.43 \mathrm{t} \mathrm{CO}_{2} \mathrm{e} / \mathrm{ha} / \mathrm{season}$ for rain-fed and continuous flooded fields, respectively.

\section{Recommendations}

The study in the four pilot countries revealed cost structure along the value chains of rice and maize, especially in activities including nursery, land preparation, sowing, transplanting, cultivation, harvesting, threshing and drying that along rice and maize farming. For rice, certain farming practices are better than other in terms of greenhouse gas emission than others. The same thing was revealed for maize, although in maize farming the main source was fertilizer application. It is therefore recommended to design policies accordingly. The greenhouse gas (GHG) emissions inventory is a way to identify emission sources and quantify them for a specific activity. If measured adequately and regularly, the inventory can be used as a management tool, allowing farmers to have visibility \& control of their GHG emissions and hence participate actively in the control of the greenhouse gas emission at their level.

\section{Acknowledgements}

The author acknowledges the useful comments and edits suggestion from experts at the Climate Change and Development in Africa (CCDA V) Conference in Victoria Falls (Zimbabwe) in November 2015 organised by Africa Climate Policy Centre. The CCDA is an annual forum designed to bolster linkages between climate science and development policy by promoting transparent discussions between key stakeholders in the climate and development community. He also acknowledges comments and edits from colleagues at the United Nations Economic Commission for Africa/Regional Integration and Trade Division/Food Security, Agriculture and Land Section, namely Dr. Stephen Karingi, Adama Coulibaly, Guy Ranaivomanana, Medhat El-Helepi, and Habtom Tesfaye for the technical support. However, any errors or omissions must be attributed to the author. The author dedicates the paper to Getu Reta, his long-term friend from Ethiopia, who passed away in 2014 and to his Mentor and friend Dr. Hussein Halane, for believing in him, his sense of leadership and coaching and is grateful to him for having guided him to be a seasoned professional in food security issues.

\section{Disclaimer}

The author stresses that views expressed in this paper are those of the author and should not be attributed to the United Nations or the United Nations Economic Commission for Africa.

\section{References}

[1] USDA Database: Index Mundi: Ghana Milled Rice Production by Year: 1960 to 2016. http://www.indexmundi.com/agriculture/?country=gh\&commodity=milled-rice\&graph=production

[2] IFPRI: Patterns of Adoption of Improved Maize Technologies in Ghana, Ghana Strategy Support Programme, IFPRI, July 2013.

[3] Africa Rice, Module 12, Harvest and Post-Harvest Operations. http://www.africarice.org/publications/nerica-comp/module\%2012_Low.pdf

[4] Crop Life International: Achieving Emissions Reductions, Crop Protection Products' Role in Creating a Sustainable Agriculture.

http://croplife.org/wp-content/uploads/pdf_files/Presentation-ERM-Role-of-Crop-Protection-in-Reducing-GHG-Emissi ons.pdf http://www.croplife.org/view_document.aspx\%3FdocId\%3D4125

[5] Koné, B., Yao-Kouamé, A., Sorho, F., Diatta, S., Sié, M. and Ogunbayo, A. (2010) Long-Term Effect of Mali Phosphate Rock on the Grain Yield of Inter Specifics and Selective Rice Cultivars on Acid Soil in a Humid Forest Zone of Côte d'Ivoire. http://www.ajol.info/index.php/ijbcs/issue/view/7884 http://www.ajol.info/index.php/ijbcs/issue/archive 
[6] International Rice Research Institute (IRRI) \& International Maize and Wheat Improvement Center (CIMMYT): Submerged Soil for Rice Production, Rice Knowledge Bank. http://www.knowledgebank.irri.org/submergedsoils

[7] Crop Life International: Achieving Emissions Reductions, Crop Protection Products’ Role in Creating a Sustainable Agriculture. http://www.croplife.org/view_document.aspx\%3FdocId\%3D4125

Submit or recommend next manuscript to SCIRP and we will provide best service for you:

Accepting pre-submission inquiries through Email, Facebook, LinkedIn, Twitter, etc.

A wide selection of journals (inclusive of 9 subjects, more than 200 journals)

Providing 24-hour high-quality service

User-friendly online submission system

Fair and swift peer-review system

Efficient typesetting and proofreading procedure

Display of the result of downloads and visits, as well as the number of cited articles

Maximum dissemination of your research work

Submit your manuscript at: http://papersubmission.scirp.org/ 